\title{
Corrigendum: Ocean Science Diplomacy can Be a Game Changer to Promote the Access to Marine Technology in Latin America and the Caribbean
}

\section{OPEN ACCESS}

Approved by:

Frontiers Editorial Office,

Frontiers Media SA, Switzerland

${ }^{*}$ Correspondence: Andrei Polejack andrei.polejack@gmail.com

Specialty section: This article was submitted to Research Policy and Strategic Management, a section of the journal Frontiers in Research Metrics and Analytics

Received: 18 May 2021 Accepted: 27 May 2021 Published: 13 July 2021

Citation:

Polejack A and Coelho LF (2021)

Corrigendum: Ocean Science Diplomacy can Be a Game Changer to

Promote the Access to Marine Technology in Latin America and the Caribbean.

Front. Res. Metr. Anal. 6:711473. doi: 10.3389/frma.2021.711473

\author{
Andrei Polejack ${ }^{1,2 *}$ and Luciana Fernandes Coelho ${ }^{1,3}$ \\ ${ }^{1}$ WMU-Sasakawa Global Ocean Institute, World Maritime University, Malmö, Sweden, ${ }^{2}$ Ministério da Ciência, Tecnologia e \\ Inovações, Brasilia, Brazil, ${ }^{3}$ Research Group Natural Resources, Law, and Sustainable Development, Brazilian Institute for the \\ Law of the Sea, Salvador, Brazil
}

Keywords: science diplomacy, access to technology, Latin America, Caribbean, UN decade of ocean science

\section{A Corrigendum on}

Ocean Science Diplomacy can Be a Game Changer to Promote the Access to Marine Technology in Latin America and the Caribbean

by Polejack, A., and Coelho, L. F. (2021). Front. Res. Metr. Anal. 6:34-36. doi:10.3389/frma.2021. 637127

In the published article, there was an error. A correction has been made to the Affiliation 3.

Instead of "Research Group Natural Resources, Law, and Sustainable Development, Brazilian Institute for the Law of the Sea, Caxias do Sul, Brazil," it should be "Research Group Natural Resources, Law, and Sustainable Development, Brazilian Institute for the Law of the Sea, Salvador, Brazil."

The authors apologize for this error and state that this does not change the scientific conclusions of the article in any way. The original article has been updated.

Copyright ( $\odot 2021$ Polejack and Coelho. This is an open-access article distributed under the terms of the Creative Commons Attribution License (CC BY). The use, distribution or reproduction in other forums is permitted, provided the original author(s) and the copyright owner(s) are credited and that the original publication in this journal is cited, in accordance with accepted academic practice. No use, distribution or reproduction is permitted which does not comply with these terms. 